\title{
Maltoporins and maltose-binding proteins of Yersinia enterocolitica
}

\author{
Katarzyna Brzostek, Halina Heleszko and Jerzy Hrebenda* \\ Institute of Microbiology, Warsaw University, Nowy Świat 67, 00-046 Warsaw, Poland
}

(Received 11 June 1992; revised 15 September 1992; accepted 23 September 1992)

\begin{abstract}
Two components of the Yersinia enterocolitica maltose transport system, maltoporin (OmpM) and an osmotically shockable periplasmic maltose-binding protein (MBP) were identified. The synthesis of OmpM (apparent $M_{\mathrm{r}}$ 43000) and transport of maltose into cells of $Y$. enterocolitica were induced by maltose and maltodextrins. A mutant lacking OmpM was drastically impaired in maltose transport, independent of induction by maltose. The MBP of $Y$. enterocolitica (apparent $M_{\mathrm{r}}$ 40000) was found in the osmotic shock fluid. Its synthesis was induced by maltose. Moreover, rabbit antibodies raised against the MBP of $E$. coli cross-reacted with the analogous protein from $Y$. enterocolitica. The MBP of $Y$. enterocolitica restored the maltose transport activities in $\triangle$ malE mutant cells of $E$. coli.
\end{abstract}

\section{Introduction}

The outer membrane $(\mathrm{OM})$ of enteric bacteria contains pore proteins (porins) that mediate the diffusion of small hydrophilic molecules (Nakae, 1976; Nikaido \& Vaara, 1985). Most porins, such as $\mathrm{OmpF}$ and $\mathrm{OmpC}$ from Escherichia coli $\mathrm{K} 12$, exhibit low specificity for solutes and act as general diffusion pathways (Nikaido \& Vaara, 1985). Other porins are induced in the OM if the bacteria are grown under special conditions. Very few substratespecific porins have been described so far: among them is LamB, a maltoporin which facilitates the diffusion of maltose and low- $M_{\mathrm{r}}$ maltodextrins (three to seven glucose residues) (Szmelcman \& Hofnung, 1975; Schwartz, 1987).

In Gram-negative bacteria, the transport of maltose and maltodextrins requires at least four other proteins. One of them is maltose-binding protein (MBP), which is located in the periplasmic space. The MBP of $E$. coli (the product of the malE gene) binds maltose and higher $\alpha(1 \rightarrow 4$ )-glucose polymers (Kellerman \& Szmelcman, 1974). This interaction is necessary for translocation of maltose or maltodextrins through the periplasmic space (for details see the reviews by Hengge \& Boos, 1983; Schwartz, 1987).

Yersinia enterocolitica is an enteric bacterium frequently involved in human gastroenteritis (Brenner, 1984). This species is phylogenetically rather distant from $E$. coli, to which other genera such as Klebsiella,

\footnotetext{
* Author for correspondence. Tel. 26-89-82.
}

Abbreviations: MBP, maltose-binding protein; MMA, minimal medium A; OM, outer membrane.
Enterobacter and Citrobacter are more closely related (Brenner, 1984; Ahmad et al., 1990; Hirvas et al., 1991).

We have identified in the OM of $Y$. enterocolitica 'major' proteins that are physicochemically and functionally similar to OmpA, OmpF and OmpC of $E$. coli (Brzostek \& Hrebenda, 1988; Brzostek \& Nichols, 1990). The OmpC of Y. enterocolitica has been isolated and characterized. In the native form, this protein probably exists as a trimer of identical monomers, which have an apparent $M_{\mathrm{r}}$ of 36000 . It behaves as a general diffusion pore with diameter of $1.0 \mathrm{~nm}$. The pore activity exhibits cation selectivity and the biosynthesis of the protein is increased at high osmolarity. These properties characterize the protein as a porin, analogous to OmpC of $E$. coli. Polyclonal antibodies against the pure $Y$. enterocolitica protein cross-react with the trimeric form of OmpC and OmpF from E. coli (Brzostek et al., 1989).

In this paper, we describe two other $Y$. enterocolitica proteins, the inducible major $\mathrm{OM}$ protein OmpM, analogous to the maltoporin LamB of $E$. coli, and $Y$. enterocolitica maltose-binding protein. In a reconstitution experiment this MBP restored maltose transport in cells of $E$. coli $\Delta$ malE.

\section{Methods}

Organisms and growth conditions. Strains of $Y$. enterocolitica and $E$. coli are listed in Table 1. Bacteria were grown in minimal medium A (MMA; Miller, 1972) containing glycerol $(0.2 \%, \mathrm{v} / \mathrm{v})$ or glycerol $(0.2 \%, v / v)$ and maltose $(0.2 \%, \mathrm{w} / \mathrm{v})$ at $28^{\circ} \mathrm{C}$ or $37^{\circ} \mathrm{C}$. Maltose (Sigma) was used as inducer for the maltose transport system. Casamino acids (Difco) $(0.2 \%, \mathrm{w} / \mathrm{v})$ were added when cells were grown at $37^{\circ} \mathrm{C}$ 
Table 1. Bacterial strains

\begin{tabular}{|c|c|c|}
\hline Strain & $\begin{array}{l}\text { Known genotype or } \\
\text { phenotype }\end{array}$ & $\begin{array}{l}\text { Source or } \\
\text { reference }\end{array}$ \\
\hline \multicolumn{3}{|l|}{ Y. enterocolitica } \\
\hline Ye5 & $\mathrm{OmpC}^{+} \mathrm{OmpF}^{+} \mathrm{OmpM}^{+}$ & Brzostek \& \\
\hline KB1001 & $\mathrm{OmpC}^{+} \mathrm{OmpF}^{-} \mathrm{OmpM}^{+}$ & Hrebenda (1988) \\
\hline KB1004 & $\begin{array}{l}\mathrm{OmpC}^{+} \mathrm{OmpF}^{+} \mathrm{OmpM}^{-} \\
\text {isolated after EMS muta- } \\
\text { genization of Ye5 }\end{array}$ & This study \\
\hline \multicolumn{3}{|l|}{ E. coli } \\
\hline MM134 & $\begin{array}{l}\text { malT }{ }^{c}-1 \text { (mal B112 leuB6 } \\
\text { his-4 tonA31 tsx78 rpsL136 } \\
\text { thi-1 aral4 mtll xyll }\end{array}$ & $\begin{array}{l}\text { Brass \& Manson } \\
\text { (1984) }\end{array}$ \\
\hline MC4100 & $\begin{array}{l}\text { araD139 } \Delta(\operatorname{argF}-\mathrm{lac}) U 139 \\
\text { rpsL150 relA1 deoC1 ptsF25 } \\
\text { flbB5301 rbsR }\end{array}$ & $\begin{array}{l}\text { Casadaban } \\
(1976)\end{array}$ \\
\hline MD15 & $\begin{array}{l}\text { araD139 } \Delta(\text { argF-lac }) U 139 \\
\text { rpsL150 relA1 deoC1 ptsF25 } \\
\text { flbB5301 rbsR malT } \\
\Delta \text { malE444 }\end{array}$ & $\begin{array}{l}\text { W. Boos, } \\
\text { University of } \\
\text { Konstanz, } \\
\text { Germany }\end{array}$ \\
\hline
\end{tabular}

Isolation of $\mathrm{OmpM}^{-}$mutants. Ye5 cells were mutagenized with ethyl methanesulphonate (EMS) according to Carlton \& Brown (1981). After mutagenesis, the bacteria were plated on maltotriose $\left(5 \times 10^{-4} \mathrm{M}\right)$ MMA medium. Thirty tiny colonies $(<0.01 \%$ of total number of colonies) were picked and purified. Each colony was replicated on maltotetraose $\left(5 \times 10^{-4} \mathrm{M}\right)$ and maltose MMA plates. After $72 \mathrm{~h}$ of growth, clones that were unable to grow on maltotetraose (nine clones) were selected and cultured in MMA with glycerol plus maltose. They were used for the isolation of OM proteins. The OM proteins from each clone were separated by electrophoresis (SDS-PAGE). Six $\mathrm{Dex}^{-} \mathrm{Mal}^{+}$ clones were $\mathrm{OmpM}^{-}$. The remaining three were $\mathrm{Dex}^{-} \mathrm{Mal}^{+} \mathrm{OmpM}^{+}$, and in further studies were disregarded.

Isolation of outer membrane proteins. OM proteins were isolated according to a modification of the method of Henning et al. (1978). Overnight cultures of the strains were diluted $(1: 100)$ in minimal medium A (MMA), grown to the late exponential phase and centrifuged $\left(6000 \mathrm{~g}\right.$ for $10 \mathrm{~min}$ at $\left.2{ }^{\circ} \mathrm{C}\right)$. The pellet was resuspended in water and sonicated for $75 \mathrm{~s}$ (five $15 \mathrm{~s}$ cycles with $30 \mathrm{~s}$ pauses). Unbroken cells were removed by centrifugation $(6000 \mathrm{~g}$ for $5 \mathrm{~min})$. The supernatant was centrifuged $\left(12000 \mathrm{~g}\right.$ for $10 \mathrm{~min}$ at $\left.2{ }^{\circ} \mathrm{C}\right)$, the pellet was washed twice with water and finally resuspended in sample buffer prior to electrophoresis (Laemmli, 1970). Samples $(30 \mu \mathrm{l})$ containing $50 \mu \mathrm{g}$ protein were incubated for $5 \mathrm{~min}$ in a boiling water bath and applied to the gel.

Preparation of periplasmic proteins. Periplasmic proteins were prepared from exponential phase cells cultured in MMA.

The cold osmotic shock procedure described by Heppel (1971) was used. In some cases, the periplasmic proteins were released by treating the cells with chloroform (Ames et al., 1984). The cold shock fluids were dialysed overnight against $30 \mathrm{~mm}$-Tris/ $\mathrm{HCl}$ buffer, $\mathrm{pH} 7.3$ and then concentrated with the use of Aquacide (Calbiochem).

$S D S-P A G E$. Electrophoresis was done in $12 \%$ (w/v) SDSpolyacrylamide gels according to Lugtenberg et al. (1975). The gels contained acrylamide and bis-acrylamide in the ratio $30: 0 \cdot 8(\mathrm{w} / \mathrm{w})$ and were stained with Coomassie brilliant blue (Laemmli, 1970).

Western blotting. Western blotting was done with nitrocellulose sheets (Millipore) according to the procedure of Towbin et al. (1979), modified as described previously (Brzostek et al., 1989). Bound rabbit antibodies against $E$. coli $\mathrm{MBP}$ were detected by peroxidase-coupled goat anti-rabbit antibodies (Jackson Immunoresearch Laboratories) using $o$-dianisidine (3,3'-dimethoxybenzidine) (Sigma) and $\mathrm{H}_{2} \mathrm{O}_{2}$.

Maltose-binding activity of shock fluids. $\left[{ }^{14} \mathrm{C}\right]$ Maltose $[5 \mu \mathrm{l}$; specific activity $\left.540 \mathrm{mCi} \mathrm{mmol}^{-1}\left(20 \mathrm{GBq} \mathrm{mmol}{ }^{-1}\right)\right]$ was added to cold shock fluid and incubated for $5 \mathrm{~min}$ at room temperature. For protein precipitation, $1 \mathrm{ml}$ of a saturated solution of ammonium sulphate was used. The samples were filtered (Millipore, $0.45 \mu \mathrm{m}$ ), washed with $5 \mathrm{ml}$ $\left(\mathrm{NH}_{4}\right)_{2} \mathrm{SO}_{4}$ solution and dried. Radioactivity was determined in a Beckman liquid scintillation counter.

Transport of $\left[{ }^{14} \mathrm{C}\right]$ maltose. Maltose uptake assays were done as described by Szmelcman \& Hofnung (1975). Bacteria were grown in MMA with maltose or glycerol at $28^{\circ} \mathrm{C}$. Cells from the exponential phase of growth were washed twice in MMA (without maltose) and resuspended in $1 \mathrm{ml}$ of MMA to identical optical densities $\left(\mathrm{OD}_{578}=\right.$ $0 \cdot 1)$. At time zero, $\left[{ }^{14} \mathrm{C}\right]$ maltose [specific activity $540 \mathrm{mCi} \mathrm{mmol}^{-1}$ $\left(20 \mathrm{GBq} \mathrm{mmol}^{-1}\right.$ ); final concentration $7.0 \times 10^{-2} \mu \mathrm{M}$ ] was added. Samples $(200 \mu \mathrm{l})$ were removed at $20,40,60,80$ and $160 \mathrm{~s}$, immediately filtered through membrane filters (Millipore, $0.45 \mu \mathrm{m}$ ) and washed with $10 \mathrm{ml}$ of MMA. The radioactivity of the dry filters was determined in a toluene-based scintillation fluid.

Reconstitution of maltose transport in $E$. coli. The procedure described by Brass et al. (1983) was used. Strains MD15 ( $\Delta$ mal E444 malT $^{c}$ ) and MM134 ( $\triangle$ malB malT $^{c}$ ) were grown in MMA plus glycerol and appropriate supplements. Exponentially growing cells $(3 \mathrm{ml}$; $2 \times 10^{9}$ cells ml${ }^{-1} ; \mathrm{OD}_{578}=1$ ) were harvested and washed with $5 \mathrm{ml}$ icecold $50 \mathrm{~mm}$-Tris/ $\mathrm{HCl}$ buffer, $\mathrm{pH} 7 \cdot 2$. The cells were then resuspended in $1 \mathrm{ml}$ of the same buffer containing $300 \mathrm{~mm}-\mathrm{CaCl}_{2}\left(0^{\circ} \mathrm{C}\right)$. After further centrifugation, the cells were suspended in $20 \mu \mathrm{lTris} / \mathrm{HCl}-\mathrm{CaCl}_{2}$ buffer $\left(0^{\circ} \mathrm{C}\right)$ and transferred to a new tube containing $20 \mu \mathrm{l}$ of $Y$. enterocolitica chloroform shock fluid (final concentration of protein about $10 \mathrm{mg} \mathrm{ml}^{-1}$ ). The sample was shaken for $30 \mathrm{~min}$ at $0{ }^{\circ} \mathrm{C}$ and the cells were then washed with $1 \mathrm{ml} 0.9 \%(\mathrm{w} / \mathrm{v}) \mathrm{NaCl}$ at room temperature. For determination of the initial rate of maltose uptake, cells treated as above were suspended at room temperature in $1 \mathrm{ml}$ of MMA containing glycerol. $\left[{ }^{14} \mathrm{C}\right]$ Maltose [specific activity $540 \mathrm{mCi} \mathrm{mmol}^{-1}$ $\left(20 \mathrm{GBq} \mathrm{mmol}{ }^{-1}\right)$; final concentration $\left.5 \times 10^{-2} \mu \mathrm{M}\right]$ was added.

\section{Results}

\section{Identification of maltoporins in $O M$ of $Y$. enterocolitica}

$Y$. enterocolitica cells grown in minimal medium with maltose synthesized an additional OM protein (OmpM) with an apparent $M_{\mathrm{r}}$ of 43000 (Fig. 1. lane 6). The synthesis of this protein was also induced by maltodextrins (data not shown). It was not visible on the gel after SDS-PAGE of OM proteins isolated from the culture growing in MMA with glycerol or glucose (Fig. 1 , lane 5). The OmpM appeared in the OM independently of culture temperature and $\mathrm{Ca}^{2+}$ concentration in the medium (data not shown).

EMS-induced $\mathrm{Dex}^{-} \mathrm{OmpM} \mathrm{M}^{-}$mutants were isolated. They grew in MMA medium with maltose as a carbon source but not in MMA containing maltotetraose. The polypeptide patterns of OM proteins isolated from one of these mutants (KB1004) are shown in Fig. 1 (lanes 7 and 8). Fig. 1 (lanes 3 and 4) indicates the level of $O M$ proteins of mutant strain $\mathrm{KB} 1001\left(\mathrm{OmpF}^{-} \mathrm{OmpC}^{+}\right.$ OmpM $\left.^{+}\right)$(Brzostek et al., 1989). 


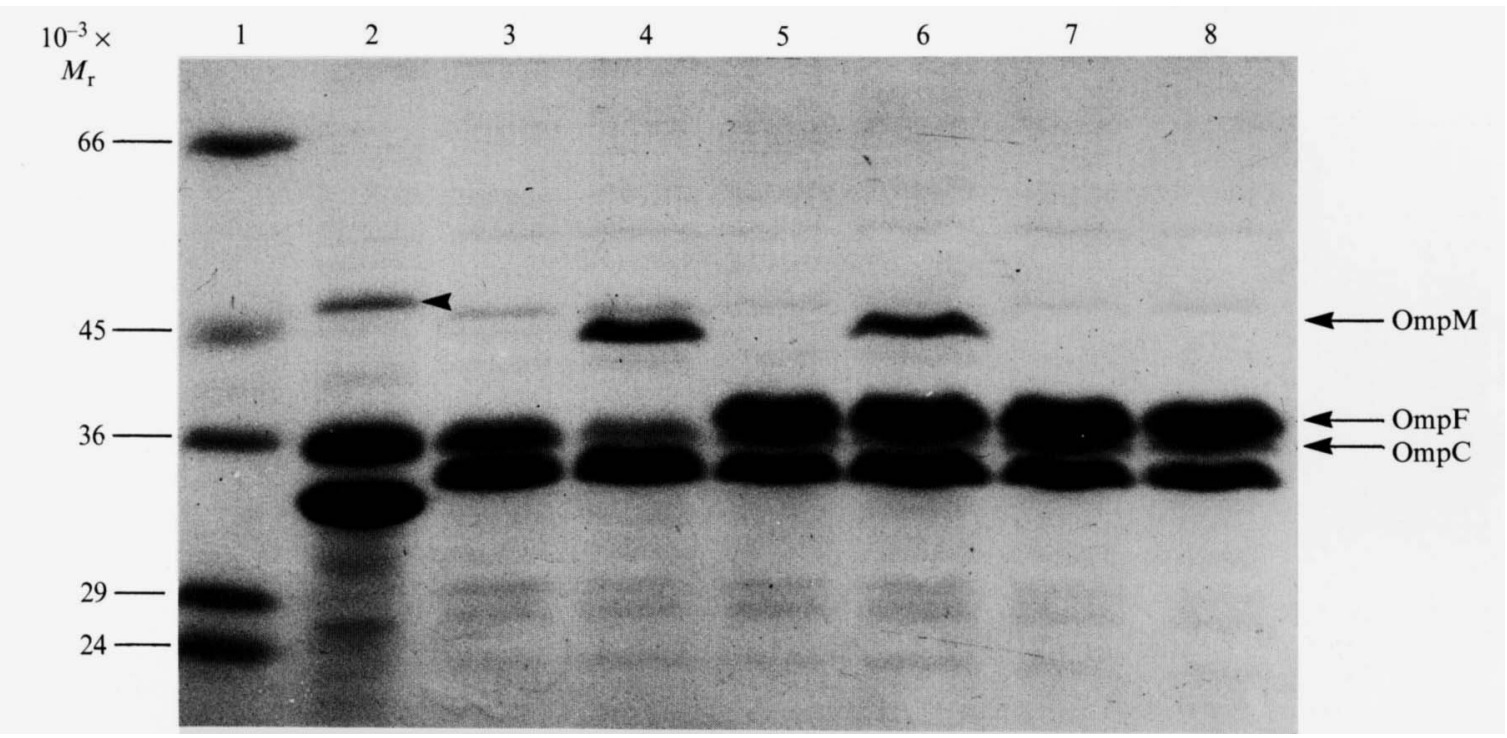

Fig. 1. SDS-PAGE of major OM proteins of $Y$. enterocolitica Ye5 (wild-type) and mutants. Bacteria were grown at $28^{\circ} \mathrm{C}$ in $\mathrm{MMA}$ containing glycerol (lanes 3,5 and 7) or glycerol and maltose (lanes 2, 4,6 and 8). A $50 \mu \mathrm{g}$ sample of each protein was loaded on to the gel. Lane 2, E. coli K12, MC4100 (control, the arrowhead indicates the position of LamB); lanes 3 and 4, Y. enterocolitica KB1001; lanes 5 and 6, Ye5; lanes 7 and 8, $Y$. enterocolitica $\mathrm{KB1004}$; lane 1, $M_{\mathrm{r}}$ markers (MW-SDS-70L; Sigma). The apparent $M_{\mathrm{r}}$ values of E. coli LamB and $Y$. enterocolitica OmpC are 50000 and 36000 respectively (Lugtenberg, 1981; Brzostek et al., 1989).

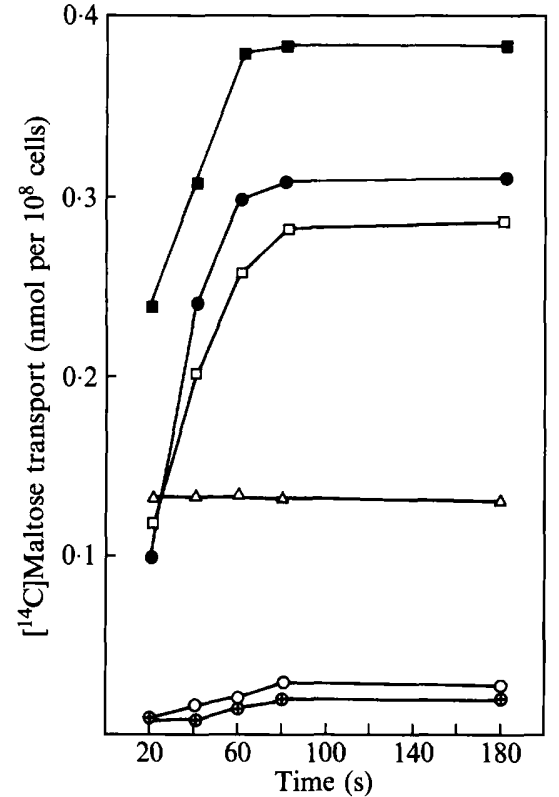

Fig. 2. Initial rate of $\left[{ }^{14} \mathrm{C}\right]$ maltose transport. Bacteria were grown in MMA with glycerol (uninduced cells) or glycerol and maltose (induced cells). At time zero, $\left[{ }^{14} \mathrm{C}\right]$ maltose was added (final concentration $\left.7 \times 10^{-2} \mu \mathrm{M}\right)$. Samples were withdrawn at different times and filtered through membrane filters. The radioactivity of the dried filters was determined. $\bigcirc, \mathrm{Ye} 5$, uninduced cells; $\boldsymbol{O}$, Ye5, induced cells; $\square$, $\mathrm{KB1001}$, uninduced cells; $\square, \mathrm{KB} 1001$, induced cells; $\triangle$, Ye5, after osmotic shock treatment; $\oplus, \mathrm{KB} 1004$, uninduced and induced cells. Data shown are means of duplicate experiments.

\section{$\left[{ }^{14} \mathrm{C}\right]$ Maltose uptake}

The initial rate of maltose transport was determined for $Y$. enterocolitica Ye5 (wild-type) and two different
Table 2. Maltose-binding activities of crude shock fluids

All strains were grown at $28^{\circ} \mathrm{C}$ in MMA medium with glycerol as a carbon source. The experiment was repeated twice with essentially the same results.

\begin{tabular}{|c|c|}
\hline Strain & $\begin{array}{c}10^{-3} \times\left[{ }^{14} \mathrm{C}\right] \text { Maltose bound } \\
\left.\text { [c.p.m. (mg protein })^{-1}\right]\end{array}$ \\
\hline \multicolumn{2}{|l|}{ E. coli } \\
\hline MC4100* & $40 \cdot 00$ \\
\hline MD15 ( $\Delta$ malE $)^{*}$ & 0.66 \\
\hline \multicolumn{2}{|l|}{$Y$. enterocolitica } \\
\hline Ye5* & $54 \cdot 00$ \\
\hline Ye5 & 1.00 \\
\hline KB1004* & $45 \cdot 10$ \\
\hline KB1004 & 1.40 \\
\hline KB $1001^{*}$ & $58 \cdot 00$ \\
\hline KB1001 & $30 \cdot 50$ \\
\hline
\end{tabular}

*Maltose was added to the medium.

mutants (KB1001 and KB1004). It was measured at a low concentration of maltose $\left(7 \times 10^{-2} \mu \mathrm{M}\right)$. The results are shown in Fig. 2. The rate of maltose transport into Ye5 cells increased about 10-fold when the cells were previously induced by maltose. The residual maltose uptake of uninduced cells represented only $6 \%$ of the wild-type activity of the induced cells. The mutant lacking OmpM (KB1004) was drastically impaired in transport, independent of maltose induction. This suggests that OmpM of $Y$. enterocolitica may function as a maltoporin.

The rate of maltose transport into uninduced KB1001 $\left(\mathrm{OmpF}^{-} \mathrm{OmpC}^{+} \mathrm{OmpM}^{+}\right)$cells was considerably higher 


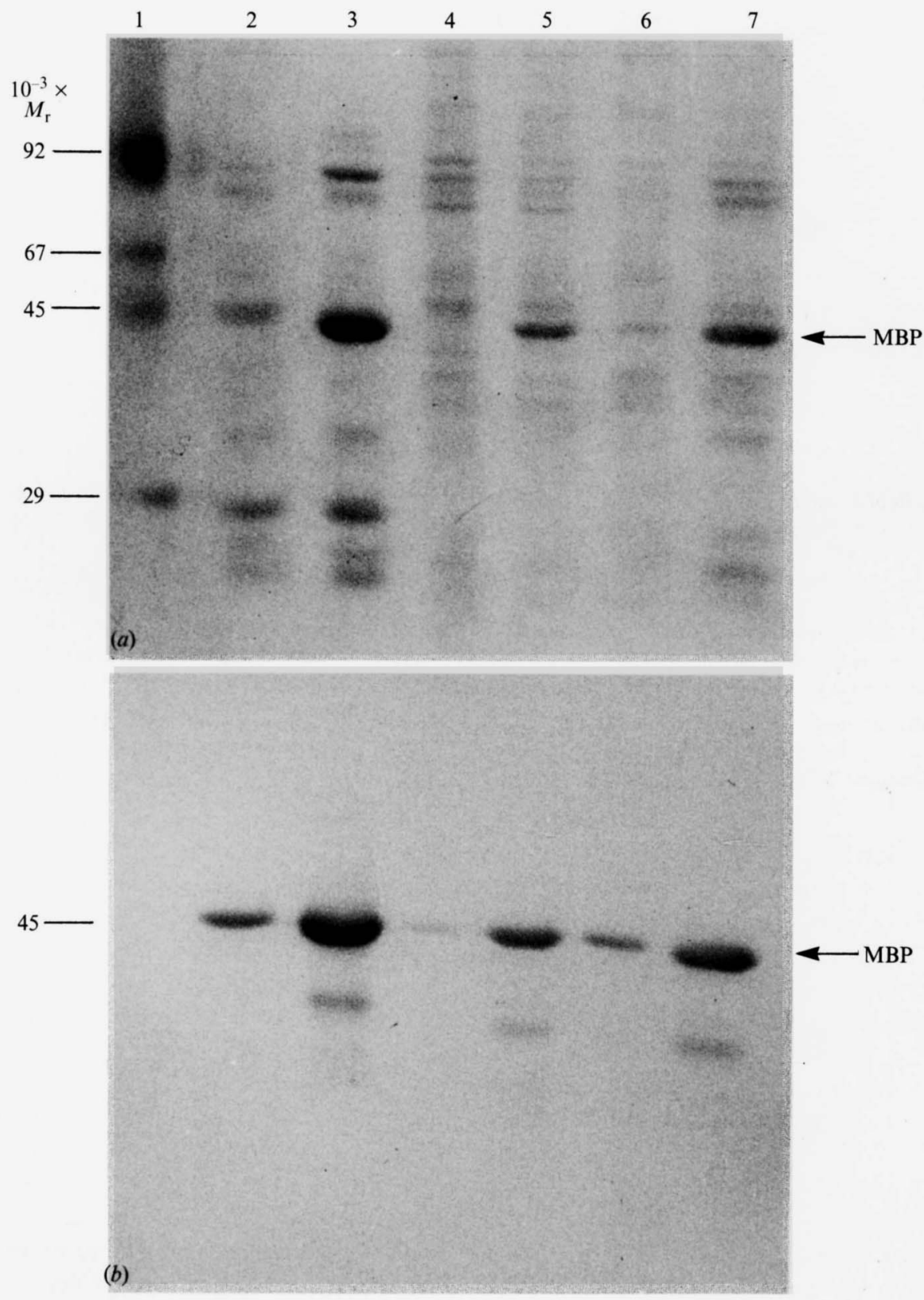

Fig. 3. SDS-PAGE analysis and Western blotting of osmotic shock fluid proteins from $Y$. enterocolitica with anti-E. coli MBP antibodies. (a) Gel stained with Coomassie blue; (b) immunoblot showing reactions of antibodies with proteins in the osmotic shock fluid. Bacteria growing in MMA with glycerol (lanes 2, 4 and 6) or glycerol plus maltose (lanes 3,5 and 7) were subjected to an osmotic shock procedure. A $50 \mu \mathrm{l}$ portion of each shock fluid sample was loaded on to the gel. Lanes 2 and 3, shock fluids from E. coli K12, MC4100; lanes 4 and 5. Y. enterocolitica Ye5; lanes 6 and 7, Y. enterocolitica KB1001; lane 1, marker proteins (mixture 4, Serva). than into uninduced cells of Ye5. It increased after induction of KB1001 cells by maltose.

\section{Maltose-binding proteins}

Transport of maltose into induced cells of $\mathrm{Ye} 5$ was strongly inhibited after osmotic shock (Fig. 2). We compared the maltose-binding activities of crude shock fluids released from induced and uninduced cells of $E$. coli and $Y$. enterocolitica. The results are summarized in Table 2. In all cases, the same experimental conditions and only one concentration of maltose ( $2.5 \mu \mathrm{M}$ final) were used. The amount of radioactivity bound to the shock proteins released from induced cells of $\mathrm{Ye} 5$ was about 50 times higher than for analogous proteins from uninduced cells. It was comparable to the radioactivity of the shock protein from induced cells of $E$. coli (MC4100) used as a control. The $E$. coli mutant MD15 does not produce maltose-binding proteins. The radioactivity of shock proteins from induced cells of MD15 $(1.5 \%$ of the binding activities of MC4100) probably represented nonspecific binding of the maltose to the osmotic shock proteins. The maltose-binding activities of crude shock fluids released from induced or uninduced KB1001 cells were higher than the activity of analogous samples obtained from Ye5. 


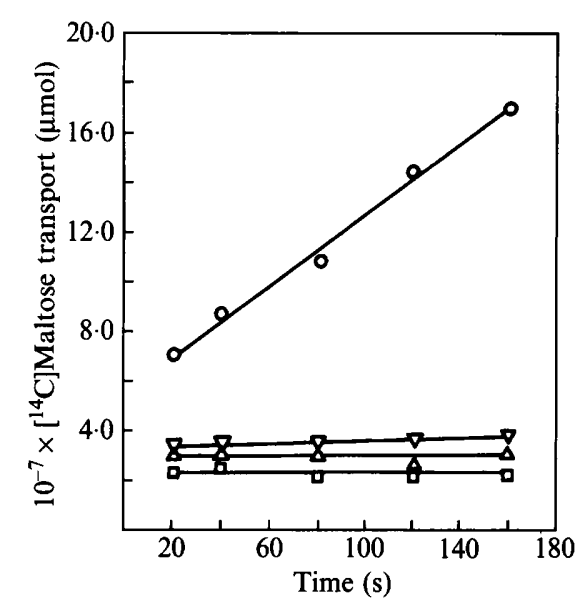

Fig. 4. Reconstitution of active transport in whole cells of $E$. coli $\Delta$ malE with shock fluid from chloroform-treated cells. Cells from exponentially growing cultures of strains MD15 ( $\Delta$ malE malT $\left.^{c}\right)$ and MM134 ( $\triangle$ malB $m a l T^{c}$ ) were subjected to the reconstitution procedure. After washing the cells with $0.9 \% \mathrm{NaCl}$, maltose uptake was measured. $\triangle, \mathrm{MD} 15$, without protein in the reconstitution mixture; $\nabla$, MD15 plus chloroform shock fluid of uninduced cells $\left(10 \mathrm{mg}\right.$ protein $\left.\mathrm{ml}^{-1}\right) ; \mathrm{O}$, MD15 plus chloroform shock fluid of induced cells; $\square$, MM134 plus chloroform shock fluid of induced cells. The results are given as the amount of maltose taken up by $1.5 \times 10^{8}$ cells. Results shown are from a single experiment, but repetition gave consistent results.

The electrophoretic (SDS-PAGE) patterns of the periplasmic osmotic shock proteins from different origins are shown in Fig. 3(a). Rabbit antibodies against MBP of $E$. coli were used to identify the $Y$. enterocolitica maltose-binding proteins by immunoblotting (Fig. $3 b$ ). The antibodies against $E$. coli $\mathrm{MBP}$ recognized the MBP in osmotic shock fluids from $E$. coli (Fig. $3 b$, lanes 2 and 3 ) and cross-reacted with analogous proteins from $Y$. enterocolitica (Fig. 3b, lanes 4 and 5). The apparent $M_{\mathrm{r}}$ of the $Y$. enterocolitica MBP was 40000 . The synthesis of this protein, in all strains tested (Ye5 and KB1001) was induced by maltose (Fig. $3 b$, lanes, 5 and 7 ).

Three main conclusions result from these experiments: (i) Y. enterocolitica produces periplasmic maltose-binding proteins; (ii) the synthesis of these proteins is induced by maltose; (iii) the MBP of $E$. coli is immunologically similar to an analogous protein of $Y$. enterocolitica.

\section{Reconstitution of maltose transport}

For the reconstitution of maltose transport in $E$. coli (strain MD15; $\Delta$ malE malT $^{c}$ ), osmotic shock fluid from uninduced or maltose-induced Ye5 cells was used. The shock proteins were not lyophilized before the experiment Strain MD15 had virtually no maltose transport activity, but such activity could be reconstituted in the same cells after pretreatment with MBP from Ye5 in Tris buffer plus $\mathrm{Ca}^{2+}$ (Fig. 4). MBP from Y. enterocolitica did not restore maltose transport in the $E$. coli control strain MM134. MM134 is a deletion mutant in malB ( $\Delta$ malB malT $^{c}$; missing all malB genes).

\section{Discussion}

A maltose-inducible OM protein similar to the LamB protein has been identified in most enterobacterial species (Palva \& Westerman, 1979; Pick \& Wöber, 1979), including Yersinia enterocolitica, $Y$. intermedia, $Y$. fredericksenii and $Y$. kristensenii (Bielecki \& Hrebenda, 1988).

In this study we have provided the following evidence to suggest that protein OmpM of $Y$. enterocolitica behaves as a maltoporin. (i) Synthesis of OmpM and transport of $\left[{ }^{14} \mathrm{C}\right]$ maltose (measured at a low external concentration) were induced by maltose or maltodextrins (maltotetraose was tested). (ii) A mutant of $Y$. enterocolitica defective in production of OmpM (KB1004) was drastically impaired in transport independently of induction by maltose. (iii) In contrast to Ye5 (wild-type), the cells of KB1004 did not grow in MMA containing maltotetraose as a carbon source but showed growth, albeit poor, in the same medium supplemented with maltose. Similar results have been obtained for the maltoporin LamB of $E$. coli (Wandersman et al., 1979), and were explained by assuming that, in the absence of the LamB protein, maltose $\left(M_{\mathrm{r}} 342\right)$ can diffuse through the general porins, whereas maltotetraose $\left(M_{\mathrm{r}} 666\right)$ is too bulky to do so. (iv) Both LamB and OmpM are murein-associated (Bielecki \& Hrebenda, 1988). The following differences between LamB and OmpM were observed: (i) the polypeptide $M_{\mathrm{r}}$ of LamB monomer is 47392 (Schwartz, 1987) whereas the apparent $M_{\mathrm{r}}$ of OmpM is only 43000 (see Fig. 1); (ii) the maltose-induced cells of $Y$. enterocolitica are resistant to bacteriophage $\lambda$.

Except in the case of most $\mathrm{Mal}^{+}$strains of Shigella and one strain of Erwinia herbicola, the maltose-inducible OM proteins in the family Enterobacteriaceae fail to interact with bacteriophage $\lambda$ (Schwartz, 1987).

Recently, we found that an $\mathrm{OmpF}^{-} \mathrm{OmpC}^{+}$mutant of $Y$. enterocolitica (KB1001) overproduces OmpC and simultaneously synthesizes a small amount of OmpM protein (Brzostek et al., 1989). However, when the cells were induced by maltose the level of OmpM in the OM increased drastically, whereas the amount of $\mathrm{OmpC}$ decreased. A similar relationship between OmpC and LamB was described by Diedrich \& Fralick (1982). In $E$. coli, this process is partially regulated at the level of transcription.

Two groups of results suggest that the transport of maltose in $Y$. enterocolitica involves an osmotically shockable, i.e. periplasmic, MBP: (i) osmotic shock treatment of maltose-induced cells of Ye5 led to a 
reduction in maltose transport in whole cells; (ii) the $\left[{ }^{14} \mathrm{C}\right]$ maltose bound to the shock proteins released from induced cells of Ye5 was 50 times higher than for analogous proteins from uninduced cells.

The MBP of $Y$. enterocolitica was identified in osmotic shock fluid from Ye5. This protein exhibits an apparent $M_{\mathrm{r}}$ of 40000 (the polypeptide $M_{\mathrm{r}}$ of $E$. coli MBP is 40661; Schwartz, 1987). Its synthesis was induced by maltose, and antibodies against the pure MBP of $E$. coli cross-reacted with the $Y$. enterocolitica MBP. The maltose-binding activity of shock fluids showed that mutant KB1001 synthesizes MBP constitutively. This was not investigated further.

In reconstitution experiments, we demonstrated that cells of a non-polar malE deletion strain of $E$. coli (MD15), which lacks periplasmic MBP but constitutively expresses the remaining $\mathrm{malB}$ genes, were partially restored for maltose transport by the import of $Y$. enterocolitica MBP into the periplasm. This means that MBP of $Y$. enterocolitica can substitute for $E$. coli MBP, and probably is able to interact with the $E$. coli inner membrane MalF, G and $\mathrm{K}$ protein complex (Shuman, 1982; Treptow \& Shuman, 1985). MBP and OmpM of $Y$. enterocolitica like some of its other proteins e.g. OmpA, OmpH, the murein lipoproteins and the porins, are probably structurally highly conserved within members of the Enterobacteriaceae (Hofstra et al., 1980; Palva, 1983; Venegas et al., 1988; Hirvas et al., 1991).

We are grateful to Professor W. Boos for the gift of E. coli strains and rabbit antibodies against $\mathrm{MBP}$.

\section{References}

Ahmad, S., Weisburg, W. G. \& Jensen, R. A. (1990). Evolution of aromatic amino acid biosynthesis and application to the fine-tuned phylogenetic positioning of enteric bacteria. Journal of Bacteriology 170, 5916-5918.

Ames, G. F.-L., Prody, C. \& Kustu, S. (1984). Simple, rapid, and quantitative release of periplasmic proteins by chloroform. Journal of Bacteriology 160, 1181-1183.

BieleCKI, J. \& HREBENDA, J. (1988). Outer membrane protein of Yersinia: major protein induced by maltose. Acta Microbiologica Polonica 37, 133-139.

Brass, J. M. \& Manson, M. D. (1984). Reconstitution of maltose chemotaxis in Escherichia coli by addition of maltose binding protein to calcium-treated cells of maltose regulon mutants. Journal of Bacteriology 157, 881-890.

Brass, J. M., EhmanN, V. \& Bukau, B. (1983). Reconstitution of maltose transport in Escherichia coli: conditions affecting import of maltose binding protein into periplasm of calcium treated cells. Journal of Bacteriology 155, 76-106.

BRENNER, D. J. (1984). Facultatively anaerobic Gram-negative rods. Family I, Enterobacteriaceae. In Bergey's Manual of Systematic Bacteriology, vol. 1, pp. 408-420. Edited by N. R. Krieg \& J. G. Holt. Baltimore: Williams \& Wilkins.

BRZOSTEK, K. \& HREBENDA, J. (1988). Outer-membrane permeability to $\beta$-lactam antibiotics in Yersinia enterocolitica. Journal of General Microbiology 134, 1535-1540.

Brzostek, K.\& Nichols, W. W. (1990). Outer membrane permeability and porin proteins of Yersinia enterocolitica. FEMS Microbiology Letters 70, 275-278.
Brzostek, K., Hrebenda, J., Benz, R. \& Boos, W. (1989). The OmpC protein of Yersinia enterocolitica: purification and properties. Research in Microbiology 140, 599-614.

Carlton, B. C. \& Brown, B. J. (1981). Gene mutation. In Manual of Methods for General Bacteriology, pp. 222-242. Edited by P. Gerhardt, R. G. E. Murray, R. N. Costilow, E. W. Nester, W. A. Wood, N. R. Krieg \& G. B. Philips. Washington, DC: American Society for Microbiology.

Casadaban, M. J. (1976). Transposition and fusion of the lac genes to selected promoters in Escherichia coli using bacteriophage lambda and mu. Journal of Molecular Biology 104, 541-555.

Diedrich, D. L. \& Fralick, J. A. (1982). Relationship between the OmpC and LamB proteins of Escherichia coli and its influence on the protein mass of the outer membrane. Journal of Bacteriology 149, $156-160$.

HeNGGe, R. \& Boos, W. (1983). Maltose and lactose transport in Escherichia coli. Examples of two different types of concentrative transport system. Biochimica et Biophysica Acta 737, 443-478.

Henning, U., Sontag, I. \& Hindennach, I. (1978). Mutants (OmpA) affecting a major outer membrane protein of Escherichia coli K-12. European Journal of Biochemistry 92, 491-498.

HEPPEL, L. A. (1971). The concept of periplasmic enzymes. In Structure and Function of Biological Membranes, pp. 223-247. Edited by L. I. Rothfield. New York: Academic Press.

HiRvas, L., Koski, P. \& VAara, M. (1991). The ompH gene of Yersinia enterocolitica: cloning, sequencing, expression, and comparison with known enterobacterial ompH sequences. Journal of Bacteriology 173, 1223-1229.

Hofstra, H., VAN TOL, M. J. D. \& VAARA, M. (1980). Cross-reactivity of major outer membrane proteins of Enterobacteriaceae, studied by crossed immunoelectrophoresis. Journal of Bacteriology 143, 328-337.

Kellerman, O. \& Szmelcman, S. (1974). Active transport of maltose in Escherichia coli K-12. Involvement of a "periplasmic" maltose binding protein. European Journal of Biochemistry 86, 27-34.

LAEMMLI, U. K. (1970). Cleavage of structural proteins during the assembly of the head of bacteriophage T4. Nature, London 227, 680-685.

LugTENBERG, B. (1981). Composition and function of the outer membrane of Escherichia coli. Trends in Biochemical Sciences 6, 262-266.

Lugtenberg, B., Meijers, J., Peters, R., Van der Hoek, P. \& Van ALPHEN, L. (1975). Electrophoretic resolution of the "major outer membrane protein" of Escherichia coli K-12 into four bands. FEBS Letters 58, 254-258.

Miller, J. H. (1972). Experiments in Molecular Genetics. Cold Spring Harbor, NY: Cold Spring Harbor Laboratory.

NAKAE, T. (1976). Identification of the major outer membrane protein of Escherichia coli that produces transmembrane channels in reconstituted vesicle membranes Biochemical and Biophysical Research Communications 71, 877-884.

NikAIDO, H. \& VAARA, M. (1985). Molecular basis of bacterial outer membrane permeability. Microbiological Reviews 49, 1-32.

Palva, A. (1983). OmpA gene in the detection of Escherichia coli and other Enterobacteriaceae by nucleic acid sandwich hybridization. Journal of Clinical Microbiology 18, 92-100.

Palva, E. T. \& Westerman, P. (1979). Arrangement of the maltoseinducible major outer membrane proteins, the bacteriophage $\lambda$ receptor in Escherichia coli and the $44 \mathrm{~K}$ protein in Salmonella typhimurium. FEBS Letters 95, 77-80.

PICK, K. H. \& WöBER, G. (1979). Maltodextrin pore proteins in the outer membrane of Escherichia coli and Klebsiella pneumoniae: immunological comparison. FEMS Microbiological Letters 5, 119-122.

SCHUMAN, J. (1982). Active transport of maltose in Escherichia coli $\mathrm{K}-12$. Role of the periplasmic maltose binding protein and evidence for a substrate recognition site in the cytoplasmic membrane. Journal of Biological Chemistry 257, 5455-5461.

SCHWARTZ, M. (1987). The maltose regulon. In Escherichia coli and Salmonella typhimurium. Cellular and Molecular Biology, pp. 1482-1502. Edited by J. L. Ingraham, K. B. Low, B. Magasanik \& 
H. E. Umbarger. Washington, DC: American Society for Microbiology.

Szmelcman, S. \& HofNung, M. (1975). Maltose transport in Escherichia coli K-12: involvement of the bacteriophage lambda receptor. Journal of Bacteriology 124, 112-118.

Towbin, H., Staehelin, T. \& GoRdon, J. (1979). Electrophoretic transfer of proteins from polyacrylamide gels to nitrocellulose sheets: procedure and some applications. Proceedings of the National Academy of Sciences of the United States of America 76, 4350-4354.

Treptow, N. A. \& Shuman, H. A. (1985). Genetic evidence for substrate and periplasmic-binding-protein recognition by the MalF and MalG protein, cytoplasmic membrane component of the Escherichia coli maltose transport system. Journal of Bacteriology 163, 654-660.

Venegas, A., Gomez, I., Zaror, I. \& YudeleVich, A. (1988). The nucleotide sequence of the Salmonella typhi ompC porin gene. Nucleic Acids Research 16, 7721-7722.

Wandersman, C., Schwartz, M. \& FerEncI, T. (1979). Escherichia coli mutants impaired in maltodextrin transport. Journal of Bacteriology 140, 1-13. 